\title{
Science Teaching Materials for Students with Special Needs: Concept of Exhaust Emissions in Transportation Equipment
}

\author{
Rina Maryanti ${ }^{1 *}$ \\ ${ }^{1}$ Departemen Pendidikan Khusus, Fakultas Ilmu Pendidikan, Universitas Pendidikan Indonesia, Indonesia \\ *Email: maryanti.rina@upi.edu
}

\begin{abstract}
The purpose of this study was to find out science learning materials for students with special needs regarding the concept of exhaust emissions in transportation equipment. The research method used experimental demonstration. We prepared research instruments for learning the concept of exhaust emissions in transportation equipment for students with special needs. The results showed that several tools and materials must be provided and several lists of research instrument questions were made. In addition to tools and materials, methods and media must also be adapted to the needs of the child. That's because the methods and media that are in accordance with the needs of students can make it easier for students to understand the learning material. We hope that the results of this study can make it easier for teachers to teach the concept of exhaust gas emission on transportation equipment, especially for students with special needs.
\end{abstract}

\section{Keywords}

Science teaching; Students with special need; Emission concept; Transportation

\section{Introduction}

The development of the automotive as a means of transportation, both on land and at sea, greatly facilitates humans in carrying out a job. In addition to speeding up and facilitating activities, on the other hand, the use of motorized vehicles also has a very bad impact on the environment, especially exhaust gases from the combustion of fuels that do not decompose or burn completely. As it is known that the process of burning fuel from a combustion engine produces exhaust gases which theoretically contain elements of $\mathrm{CO}, \mathrm{NO}_{2}, \mathrm{HC}, \mathrm{C}, \mathrm{H}_{2}, \mathrm{CO}_{2}, \mathrm{H}_{2} \mathrm{O}$, and $\mathrm{N}_{2}$, many of which pollute the surrounding environment in the form of air pollution [1]. The element of carbon monoxide (CO) gas that affects the health of living things needs to get a special study because the carbon monoxide element produced by combustion is toxic to human blood during respiration, as a result of reduced oxygen in the blood tissue [2]. The amount of CO in the blood, the duration of inhalation, and the rate of breathing determines the amount of carboxy-hemoglobin (combination of hemoglobin/carbon-monoxide) in the blood, and if the amount of $\mathrm{CO}$ has reached a certain amount/saturated in the body, it will cause death.

The pollutants from exhaust gases that are very detrimental to health are $\mathrm{NO}_{\mathrm{x}}, \mathrm{HC}, \mathrm{CO}$ [3]. $\mathrm{NO}_{\mathrm{x}}$ gas can cause shortness of breath in asthmatics, often causes difficulty sleeping, coughs, and can also cause fog or smoke. $\mathrm{NO}_{\mathrm{x}}$ is a colorless, odorless, tasteless gas, and with $\mathrm{O}_{2}$, it is very easy, reacts quickly, and turns into $\mathrm{NO}_{2}$ because it combines with $\mathrm{O}_{2}$ [4]. $\mathrm{NO}_{2}$ gas (nitrogen dioxide) can also damage lung tissue, and if together with $\mathrm{H}_{2} \mathrm{O}$, it will form nitric acid $\left(\mathrm{HNO}_{3}\right)$, which in turn can cause acid rain, which is very dangerous for the environment [5]. $\mathrm{NO}_{\mathrm{x}}$ gas is formed due to the high temperature of combustion.

Hydrocarbons (HC) are a gas that is not so harmful to humans but is the cause of the occurrence of mixed smog (smog) [5]. The emission of hydrocarbons contained in the exhaust gas is in the form of unburned gasoline. Hydrocarbons are found in the process of vaporizing fuel in the tank, carburetor, and gas leaks that pass through the gap between the cylinder and the piston that enters the crankshaft, which is commonly called blow-by gases.

As explained earlier that carbon monoxide (CO) as gas is quite a lot in the air, where this gas is formed due to incomplete combustion. Carbon monoxide gas is odorless, tasteless, and colorless. Motor vehicles contribute greatly to the increase in harmful CO- levels [6]. In all air pollutants, $\mathrm{CO}$ is the most important pollutant.

Currently, many studies discuss transportation exhaust emissions, ranging from the concept of transportation exhaust emissions [7], transportation exhaust gas emission processes [8], the impact of transportation exhaust emissions on health [9], the impact of transportation exhaust emissions on the environment 
[10], and efforts to tackle transportation exhaust emissions [11]. However, until now, there has been no research that discusses science learning materials for students with special needs regarding the concept of exhaust emissions in transportation equipment.

Knowledge of the dangers of exhaust gas emissions from transportation equipment is very important for students with special needs. They need the knowledge to take better care of their health, especially in dealing with exhaust emissions that are often encountered in everyday life. Students with special needs are students who have various problems in the learning process [12]-[15]. Problems occur in both developmental and academic aspects [16]-[18]. So they need special education and services [19], [20]. Materials, methods, and media must be adapted to the needs of students.

This study aimed to find out science learning materials for students with special needs regarding the concept of exhaust emissions in transportation equipment. The experimental demonstration was used in this study. The research instrument was prepared for learning the concept of exhaust emissions in transportation equipment for students with special needs. The results of the study showed that there are several lists of questions that are used as instruments, as well as tools and materials that must be provided. In addition to tools and materials, methods and media must also be adapted to the needs of the child. Methods and media that were in accordance with student needs can make it easier for students to understand the learning material. The results of this study were expected to make it easier for teachers to teach the concept of exhaust gas emissions on transportation equipment, especially for students with special needs. The novelty of this research was the subject of learning objectives, namely students with special needs and the material on the concept of exhaust emissions.

\section{Theoretical Framework}

\subsection{Definition of exhaust emissions}

Exhaust gas emissions are pollutants that pollute the air produced by vehicle exhaust gases, especially transportation equipment [21]. The vehicle exhaust gas referred to here is the residual gas from the combustion process, which is discharged into the free air through the vehicle exhaust duct. There are principal emissions produced by vehicles. Exhaust gas emissions are defined as follows: Exhaust gas produced from the combustion of fuel and air consists of many gas components, most of which are polluting to the environment. The gases that become polluted are mostly the result of unavoidable by-products. As it is known that the air around us contains approximately $21 \%$ oxygen and $79 \%$ consists mostly of nitrogen and the rest is other gases in very small quantities, while fuels are generally in the form of carbon bonds $\left(\mathrm{C}_{\mathrm{x}} \mathrm{H}_{\mathrm{y}}\right)$, which also contain other elements that are bound into it [22]. According to PP No.41 of 1999 concerning air pollution control, what is meant by emission is substances, energy, and/other components produced from an activity that enters and/or enters into ambient air which has and/does not have the potential as a pollutant element [23]. Emission source is every business and/activity that emits emission from a movable source, specific movable source, immovable source, and specific immovable source.

\subsection{Exhaust emission content}

The content of emissions in exhaust gases include:

- Carbon Dioxide $\left(\mathrm{CO}_{2}\right) \cdot \mathrm{CO}_{2}$ gas is a colorless or odorless gas. $\mathrm{CO}_{2}$ is obtained from a balanced combination of fuel and oxygen to produce $\mathrm{CO}_{2}$ [5].

- Carbon Monoxide (CO). Carbon monoxide is a gas obtained because the ratio between fuel and air is not balanced. Too much fuel or $\mathrm{C}$ element cannot bind with $\mathrm{O}_{2}$, so that $\mathrm{CO}$ is formed due to incomplete combustion [5].

- Sulfur Oxide $\left(\mathrm{SO}_{2}\right)$. Gasoline/gasoline fuel contains elements of sulfur (Sulfur). When a reaction occurs in combustion, $\mathrm{S}$ will react with $\mathrm{H}$ and $\mathrm{O}$ to form sulfate compounds and sulfur oxides [5].

- Nitrogen Oxide (NO). This gas occurs due to the high heat in the combustion process so that the nitrogen content reacts with the air so that it turns into $\mathrm{NO}_{\mathrm{x}}$ [24].

- Water $\left(\mathrm{H}_{2} \mathrm{O}\right) . \mathrm{H}_{2} \mathrm{O}$ is the result of the combustion reaction in the combustion chamber. The moisture content that comes out of the combustion chamber indicates the extent to which the quality of the material fuel is used. The greater the water vapor produced, the cleaner the emissions produced [25].

- Hydrocarbon (HC). Hydrocarbon Gas occurs due to incomplete combustion in the combustion chamber. The aroma produced from the gas is very sharp and black [26].

- $\mathrm{Pb}$ (Lead) In the combustion reaction, lead does not react and becomes lead when it comes out of the combustion process [27].

- Particulates are produced from fuel residues that do not burn in the combustion chamber and exit through vehicle exhaust gases. The particle size is about 10 micrometers, so that it is easy to enter into the respiratory tract. While the smaller size can irritate the eyes [28]. 


\subsection{Impact of exhaust emissions}

Motor vehicle emissions are believed to cause and have a wide contribution to public health problems [29]. Disorders commonly known as a result of motor vehicle emissions include respiratory tract disorders, headaches, eye irritation, triggering asthma attacks, heart disease, and decreased intelligence quality in children. Motor vehicle emissions cause cancer. The effect of motor vehicle exhaust emissions on health is that it can cause irritation and contamination of the respiratory tract in the lungs [30]. This can be caused by sulfur, $\mathrm{NO}_{\mathrm{x}}$, Ozone, and other components. In a relatively long time, these conditions will develop and can lead to bronchitis, lung disorders, and pneumonia. Vehicle exhaust gases can lead to an increase in lead concentrations in the blood, which causes a decrease in the ability to absorb oxygen.

\subsection{How to tackle exhaust emissions}

Efforts are often made to reduce motor vehicle exhaust emissions, usually with the term go green. Usually, go green for re-greening in the environment. The criteria for plants that can reduce air pollution are those that have fine hairs, rough leaf surfaces, scaly leaves, jagged leaf edges, needle leaves, leaves with a sticky surface. These are effective for absorbing pollutants [31]. Plants that have high $\mathrm{NO}_{2}$ uptake from shrubs include red lollipops, kihujan, red akalipa, yellow lollipops, red Nusa Indah, lumpurkan leaves, purple and red bougainvillea, glass plate, miana, red hanjuang, azaleas, purple lantana, and green akalipa White. Meanwhile, plants that have high NO uptake from tree groups are dadap Kuning, calliandra, Trembesi, and guava [32].

\section{$3 \quad$ Methodology}

This research is devoted to discussing the concept of exhaust emissions in transportation equipment for students with special needs. The research target subjects were students with special needs in West Java. We prepared research instruments for learning the concept of exhaust emissions in transportation equipment for students with special needs. The data collection method used is through literature and field studies. We analyzed the deepening of the concept of exhaust gas emission in transportation equipment and the characteristics and needs of students with special needs. As a basis for making research instruments for studying exhaust emissions in transportation equipment for students with special needs.

\section{$4 \quad$ Results and Discussion}

\subsection{Transportation exhaust emission concept material}

Transportation emissions are emissions or releases of exhaust gases originating from the transportation sector [33]. Exhaust gas in question is exhaust gas originating from motor vehicles that are emitted or emitted into the ambient air in the form of gas from various types of pollutants and particles. The main cause of air pollution due to motor vehicle exhaust is due to the poor quality of the fuel oil used, traffic jams, and traffic behavior on the highway.

Figure 1 shows the process of exhaust gas emissions in transportation equipment, where the combustion engine produces exhaust gases from combustion, which are channeled through the exhaust to be removed.

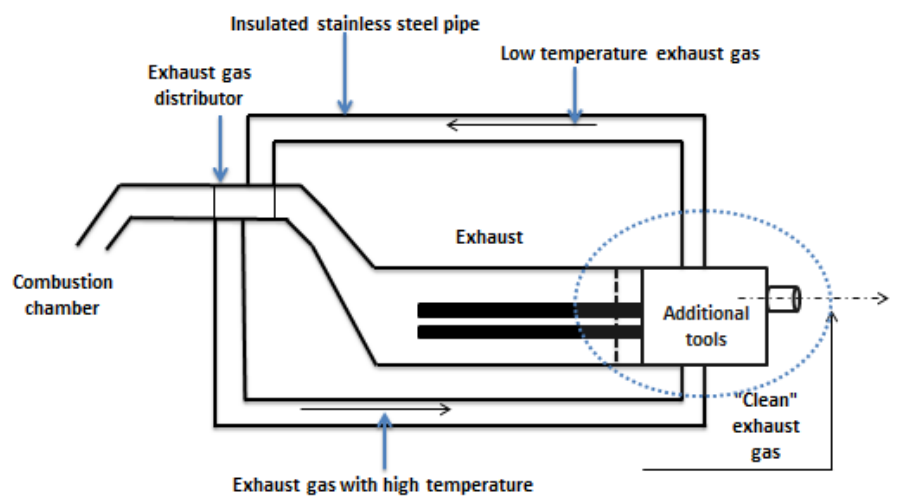

Figure 1 Illustration of exhaust gas emission process.

Figure 2 describes the illustration of experimental demonstration activities that will be carried out in the learning process of exhaust gas concept material on transportation equipment. Experiments were carried out using tools and materials, namely: paper, matches, cans, stainless steel pipes, ceramic glue, and wet white cloth. The first step of the experiment is to assemble the tool as shown in the picture, the second is to burn the paper, and the third is to ask the children to observe the process, especially the exhaust gas on a white wet cloth. 


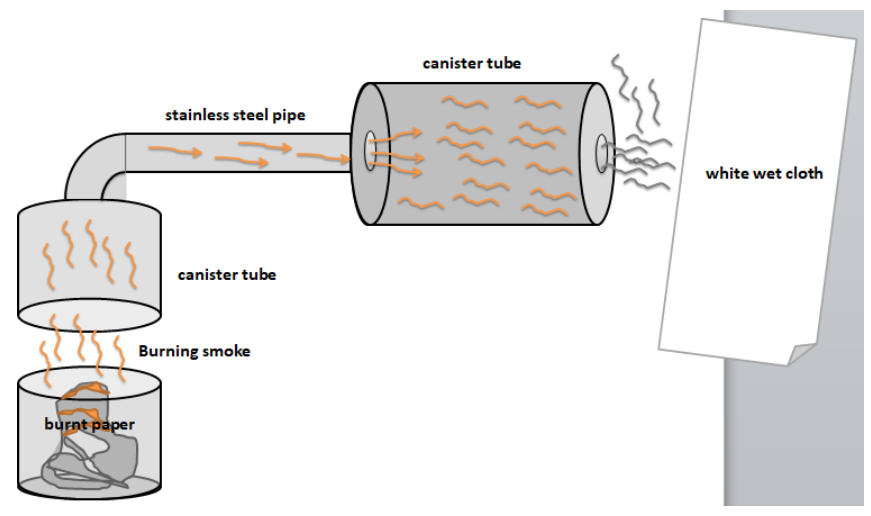

Figure 2 Illustration of exhaust gas emission process for students with special needs.

The experimental demonstration process has the aim of making students with special needs understand what transportation exhaust emissions are, how the process is, and what dangers or negative impacts are caused to the body, and how to respond to them. This is done so that students with special needs better understand the material being taught. They need concrete learning because they have difficulty understanding abstract things [15]. Concrete and interesting media are needed in the student learning process.

\subsection{Learning instruments for exhaust gas emission concepts of transportation for students with special needs}

The learning instrument for the concept of transportation exhaust emissions was made to know how big the level of understanding of students with special needs is in understanding the material being taught. This material is important to be taught because it relates to activities that students often encounter in everyday life. Knowledge of this material makes students aware of the dangers and what to do to maintain health. Most students with special needs have limited knowledge about maintaining health, especially students with intellectual disabilities [14].

Table 1 shows the research instrument regarding the learning material for the concept of exhaust emissions in transportation equipment. This instrument is given to find out how big the percentage change in the level of understanding of students with special needs regarding this material. The instrument was used at the pretest and posttest. The instrument consists of ten statements with yes and no answers. Score 1 if you answer yes and score 0 if you answer no.

Table 1 Exhaust gas emission concept material instrument for students with special needs.

\begin{tabular}{|c|c|c|c|c|c|c|}
\hline \multirow{3}{*}{ No } & \multirow{3}{*}{ Questions } & \multicolumn{4}{|c|}{ Answers } & \multirow{3}{*}{ Desc } \\
\hline & & \multicolumn{2}{|c|}{ Pretest } & \multicolumn{2}{|c|}{ Posttest } & \\
\hline & & Yes & No & Yes & No & \\
\hline 1 & Do you know what transportation exhaust emissions are? & & & & & \\
\hline 2 & Do you know the gas content in the exhaust emissions of transportation? & & & & & \\
\hline 3 & Do you know the process of transportation exhaust emissions? & & & & & \\
\hline 4 & Do you know the black transportation exhaust emissions? & & & & & \\
\hline 5 & Did you know that vehicle exhaust is a transportation exhaust emission? & & & & & \\
\hline 6 & Did you know $\mathrm{CO}_{2}$ is one of the exhaust emissions of transportation? & & & & & \\
\hline 7 & Do you know the dangers of transportation exhaust emissions for the body? & & & & & \\
\hline 8 & Do you know that transportation exhaust emissions are harmful to breathing? & & & & & \\
\hline 9 & $\begin{array}{l}\text { Do you know what efforts are being made to protect the body from the dangers of transportation exhaust } \\
\text { emissions? }\end{array}$ & & & & & \\
\hline 10 & Is wearing a mask an effort to protect the body from the dangers of transportation exhaust emissions? & & & & & \\
\hline
\end{tabular}

\subsection{Mechanical alloys method}

Air pollution is caused by the increasing number of motorized vehicles for transportation, which also increases fuel consumption. In line with these conditions, the exhaust gases released into the environment increase, and one of the major impacts is global warming that occurs due to the release of harmful gases from the combustion process. In Indonesia, more than $70 \%$ of polluted air is caused by vehicle emissions [34]. Motor vehicles will produce $\mathrm{CO}, \mathrm{CO}_{2}, \mathrm{HC}, \mathrm{NO}_{\mathrm{x}}$ gases which can have a negative impact on human health and the environment [3].
Knowledge and understanding of exhaust emissions of transportation means are important for students, especially students with special needs. They must understand the concept, process, gas content, hazards, and efforts to overcome transportation exhaust emissions, especially how to maintain a healthy body from the dangers of transportation exhaust emissions. This is because some students with special needs have poor skills in maintaining health protocols. Students with special needs are students who have problems in developmental and academic aspects [14]. This has an impact on the learning process, thus requiring special education and services. Media and methods must be adapted to the needs of students [16]. The curriculum used is also a differentiated curriculum. The 
curriculum is a bridge to achieve the goals of the national curriculum and learning objectives that are tailored to the needs of students. The national curriculum and the results of the assessment (weaknesses, strengths, and needs) of students become the main foundation in making a differentiated curriculum [17]. This makes researchers think about how the concept of learning will be carried out for students with special needs in studying the material for transportation exhaust emissions. To facilitate this, we created this research instrument.

\section{Conclusion}

This study discussed science learning materials for students with special needs regarding the concept of exhaust emissions in transportation equipment. The experimental demonstration was used in this study. The research instrument for learning the concept of exhaust emissions in transportation equipment for students with special needs was created by us. The results showed that several tools and materials must be provided. In addition, several lists of research instrument questions were made by us for further research. In addition to tools and materials, methods and media must also be adapted to the needs of the child. That's because the methods and media that were in accordance with the needs of students can make it easier for students to understand the learning material. We hope that the results of this study can make it easier for teachers to teach the concept of exhaust gas emissions on transportation equipment, especially for students with special needs.

\section{References}

[1] L. R. Sassykova et al., "The main components of vehicle exhaust gases and their effective catalytic neutralization," Orient. J. Chem., vol. 35, no. 1, p. 110, 2019.

[2] J. J. Rose et al., "Carbon monoxide poisoning: pathogenesis, management, and future directions of therapy," Am. J. Respir. Crit. Care Med., vol. 195, no. 5, pp. 596-606, 2017.

[3] D. Lovarelli and J. Bacenetti, "Exhaust gases emissions from agricultural tractors: State of the art and future perspectives for machinery operators," Biosyst. Eng., vol. 186, pp. 204-213, 2019.

[4] R. Pawankar et al., "Asia Pacific Association of Allergy Asthma and Clinical Immunology White Paper 2020 on climate change, air pollution, and biodiversity in AsiaPacific and impact on allergic diseases," Asia Pac. Allergy, vol. 10, no. 1, 2020.

[5] H. Aydin and C. İlkiliç, "Air pollution, pollutant emissions and harmfull effects," J. Eng. Technol., vol. 1, no. 1, pp. 8$15,2017$.

[6] N. Hooftman, M. Messagie, J. Van Mierlo, and T. Coosemans, "A review of the European passenger car regulations-Real driving emissions vs local air quality," Renew. Sustain. Energy Rev., vol. 86, pp. 1-21, 2018.

[7] K. Kolbe, "Mitigating urban heat island effect and carbon dioxide emissions through different mobility concepts:
Comparison of conventional vehicles with electric vehicles, hydrogen vehicles and public transportation," Transp. Policy, vol. 80, pp. 1-11, 2019.

[8] P. Lijewski, J. Merkisz, P. Fuć, A. Ziółkowski, Ł. Rymaniak, and W. Kusiak, "Fuel consumption and exhaust emissions in the process of mechanized timber extraction and transport," Eur. J. For. Res., vol. 136, no. 1, pp. 153160, 2017.

[9] A. Poorfakhraei, M. Tayarani, and G. Rowangould, "Evaluating health outcomes from vehicle emissions exposure in the long range regional transportation planning process," J. Transp. Heal., vol. 6, pp. 501-515, 2017.

[10] L. Huang, Y. Wen, X. Geng, C. Zhou, and C. Xiao, "Integrating multi-source maritime information to estimate ship exhaust emissions under wind, wave and current conditions," Transp. Res. Part D Transp. Environ., vol. 59, pp. 148-159, 2018.

[11] A. K. Sharma, P. K. Sharma, V. Chintala, N. Khatri, and A. Patel, "Environment-friendly biodiesel/diesel blends for improving the exhaust emission and engine performance to reduce the pollutants emitted from transportation fleets," Int. J. Environ. Res. Public Health, vol. 17, no. 11, p. 3896, 2020.

[12] R. Maryanti, A. Hufad, S. Sunardi, A. B. D. Nandiyanto, and A. S. M. Al-Obaidi, "Understanding covid-19 particle contagion through aerosol droplets for students with special needs," J. Eng. Sci. Technol., vol. 15, no. 3, pp. 19091920, 2020.

[13] R. Maryanti, A. Hufad, Sunardi, A. B. D. Nandiyanto, and T. I. B. Manullang, "Understanding Coronavirus (COVID19) as a Small Particle to Students with Special Needs," Horizon, vol. 2, no. 1, pp. 121-130, 2020.

[14] R. Maryanti, A. B. D. Nandiyanto, T. I. B. Manullang, A. Hufad, and S. Sunardi, "Adsorption of dye on carbon microparticles: physicochemical properties during adsorption, adsorption isotherm and education for students with special needs," Sains Malaysiana, vol. 49, no. 12, pp. 2949-2960, 2020

[15] R. Maryanti, A. Hufad, S. Sunardi, and A. B. D. Nandiyanto, "Analysis of Curriculum for Science Education for Students with Special Needs in Vocational High Schools," J. Tech. Educ. Train., vol. 13, no. 3, pp. 54-66, 2021.

[16] A. B. D. Nandiyanto et al., "Teaching 'nanotechnology' for elementary students with deaf and hard of hearing," J. Eng. Sci. Technol., vol. 13, no. 5, pp. 1352-1363, 2018.

[17] D. S. Hidayat, C. Rahmat, N. Fattah, E. Rochyadi, A. Nandiyanto, and R. Maryanti, "Understanding Archimedes law: What the best teaching strategies for vocational high school students with hearing impairment," J. Tech. Educ. Train., vol. 12, no. 1, 2020.

[18] R. Maryanti, A. Hufad, S. Tukimin, A. B. D. Nandiyanto, and T. I. B. Manullang, "The importance of teaching viscosity using experimental demonstration from daily products on learning process especially for students with special needs," J. Eng. Sci. Technol., vol. 15, pp. 19-29, 2020.

[19] R. Maryanti, A. Hufa, A. B. D. Nandiyanto, and S. Tukimin, "Teaching Heat Transfer on Solid-to-Liquid Phase Transition Phenomena to Students with Intellectual Disabilities," J. Eng. Sci. Technol., vol. 16, no. 3, pp. 2245-2259, 2021.

[20] R. Maryanti, A. Hufad, A. B. D. Nandiyanto, and S. Tukimin, "Teaching the corrosion of iron particles in saline water to students with special needs," J. Eng. Sci. Technol., vol. 16, no. 1, pp. 601-611, 2021.

[21] A. Talla, P. S. Ngohe-Ekam, and A. T. Nkeumaleu, "Evaluation of the impact of motorcycles in urban transport on air pollution: A case of Douala City in Cameroon," $J$. 
Sci. Res. Reports, pp. 1-11, 2018

[22] W. W. B. P. S. Heijkers and V. H. P. D. Annemie, "Nitrogen fixation by gliding arc plasma: better insight by chemical kinetics modelling," ChemSusChem, vol. 10, p. $2110,2017$.

[23] B. T. Bawono and A. Mashdurohatun, "Penegakan Hukum Pidana Di Bidang Illegal Logging Bagi Kelestarian Lingkungan Hidup Dan Upaya Penanggulangannya," $J$. Huk., vol. 26, no. 2, pp. 590-611, 2021.

[24] M. D. Sirignano, V. Nair, B. Emerson, J. Seitzman, and T. C. Lieuwen, "Nitrogen oxide emissions from rich premixed reacting jets in a vitiated crossflow," Proc. Combust. Inst., vol. 37, no. 4, pp. 5393-5400, 2019.

[25] A. Moharamian, S. Soltani, M. A. Rosen, S. M. S. Mahmoudi, and T. Morosuk, "Exergoeconomic analysis of natural gas fired and biomass post-fired combined cycle with hydrogen injection into the combustion chamber," $J$. Clean. Prod., vol. 180, pp. 450-465, 2018.

[26] N. S. G. Mugo, D. M. Nyaanga, S. F. Owido, and G. O. Owino, "Flue Gas Emissions and Performance Evaluation of Small-scale Solid Waste Incinerators at Njokerio and Ng'ondu in Njoro, Kenya," J. Eng. Res. Reports, pp. 5066, 2020.

[27] R. Das, A. T. B. M. Mohtar, D. Rakshit, D. Shome, and X. Wang, "Sources of atmospheric lead $(\mathrm{Pb})$ in and around an Indian megacity," Atmos. Environ., vol. 193, pp. 57-65, 2018.

[28] T. Jayarathne et al., "Nepal Ambient Monitoring and Source Testing Experiment (NAMaSTE): emissions of particulate matter from wood-and dung-fueled cooking fires, garbage and crop residue burning, brick kilns, and other sources," Atmos. Chem. Phys., vol. 18, no. 3, pp. 2259-2286, 2018

[29] I. Manisalidis, E. Stavropoulou, A. Stavropoulos, and E. Bezirtzoglou, "Environmental and health impacts of air pollution: a review," Front. public Heal., vol. 8, p. 14, 2020.

[30] M. U. Ali, G. Liu, B. Yousaf, H. Ullah, Q. Abbas, and M. A. M. Munir, "A systematic review on global pollution status of particulate matter-associated potential toxic elements and health perspectives in urban environment," Environ. Geochem. Health, vol. 41, no. 3, pp. 1131-1162, 2019.

[31] K. Manna and S. K. Srivastava, “Fe3O4@ carbon@ polyaniline trilaminar core-shell composites as superior microwave absorber in shielding of electromagnetic pollution," ACS Sustain. Chem. Eng., vol. 5, no. 11, pp. 10710-10721, 2017.

[32] H. A. Souza et al., "Guava waste to sustain guava (Psidium guajava) agroecosystem: nutrient 'balance' concepts," Front. Plant Sci., vol. 7, p. 1252, 2016.

[33] M. Dzikuć, J. Adamczyk, and A. Piwowar, "Problems associated with the emissions limitations from road transport in the Lubuskie Province (Poland)," Atmos. Environ., vol. 160, pp. 1-8, 2017.

[34] I. Sukarno, H. Matsumoto, and L. Susanti, "Transportation energy consumption and emissions-a view from city of Indonesia," Futur. Cities Environ., vol. 2, no. 1, pp. 1-11, 2016 